\title{
Bio-Molecular assay of cyanobacteria on response to diazinon an Organophosphorus insecticide.
}

\author{
Ghadai A.K., Kumar S. and Acharya D.K. \\ Department of Biotechnology, G.I.E.T.Gunupur, Rayagada-765022, Orissa, \\ alekha_ghadai2006@yahoo.co.in
}

\begin{abstract}
A comparative bio-molecular assay was made on the two cyanobacterial isolates i.e. Anabaena cylindrica and Oscillatoria tenue to study the effect of different concentration of Diazinon, an organophosphorus insecticide. We have carried out these experiments to investigate the response of different concentration of Diazinon. Finally Maximum Allowable Concentration (MAC) of Diazinon on Cyanobacterial isolates was observed. Heterocystous forms of cyanobacteria are more sensitive to pesticide than that the non-heterocystus forms of cyanobacteria. Cyanobacterial isolates were treated with different concentrations of Diazinon i.e., 1ppm, 3ppm, 5ppm, 7ppm \& 10ppm. The growth, macromolecular content of carbohydrate, protein, amino acid and nitrogen was observed. The experiments were carried out for 28 days, and it was observed that the higher concentration i.e., 9ppm and $10 \mathrm{ppm}$ of Diazinon are adversely affecting the growth \& the macromolecular contents of cyanobacterial isolates. It is also found that at late exponential phase (even in untreated conditions) the experimental macromolecular content was high in the isolates.
\end{abstract}

Keywords: Diazinon, Cyanobacteria, Macromolecular content

\section{Introduction}

Pesticides are used in varying amount on crops to maintain yield and quality. The influence of herbicides and pesticides on cyanobacteria has been investigated in many studies $[4,5]$ though most have been restricted to laboratory cultures. The responses of cyanobacteria have been studied individually and in combination to pesticides ever since last five decades [11, 12, 13, 14, and 15]. Cyanobacteria have been proved to resist the action of some pesticides [6]. Cyanobactrial are in general quite sensitive to herbicides, because they share many of the physiological features of higher plants [3] which form the site of herbicides action. The preemergence herbicide, benthiocarb was highly toxic to strains of Nostoc and Anabaena. However Nitrogen fixing cyanobacteria are mostly relatively tolerant to 2 , 4D (2, 4dichlorophenoxy acetic acid) at least under field conditions [3]. Differences have been found between the tolerance to herbicides of Cyanobacteria and that of other organisms. A number of herbicide resistant mutant of cyanobacteria have been isolated from rice field and obtained in laboratory studies [10] a comparative effect of carbomate pesticide, carbofuran, on nine heterosystus cyanobacteria showed that Anabaena fertilissima and Nostoc commune were the more sensitive [9]. Three other pesticides (based on carbaryl, dimethate or endosulphan) tested on heterocystus genera also showed wide difference between species [1]. Perhaps, it is evident that many pesticides at the recommended field application have had none or accelerating effect on growth of cyanobacteria but may affect various physiological processes like nitrogenase activity, photosynthesis, carbon fixation and enzyme of assimilatory nitrate reduction and ammonia assimilation in cyanobacteria. In this perception an investigation was carried out to study the response of commercial organophosphorous insecticide Diazinon at concentrations of $1,3,5,7,9$ and 10ppm on the growth, carbohydrate, protein, amino acids, nitrogen for every four days up to twenty eight days.

\begin{abstract}
Materials and methods
Experimental strains, Anabaena cylindrica and Oscilataria tenue are two heterocystus and non heterocystous forms respectively were collected from some local water bodies and paddy field soils of Gunupur area. These were isolated, then pure cultured in BG II media under controlled laboratory condition. The organisms were subjected to different concentration of $1,3,5,7,10 \& 12 \mathrm{ppm}$ of organophosphourous insecticide Diazinon. Samples were taken after every four days up to 28 days for the bimolecular assay of chlorophyll-a, carbohydrate, protein, amino acid and Nitrogen.
\end{abstract}

\section{Results and Discussions}

Growth in terms of chlorophyll-a was affected in both isolates. However $A$. cylindrica showed

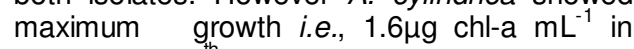
control of $20^{\text {th }}$ day, while the growth was declined at higher concentrations (Fig. I). Similarly, the growth of $O$. tenue was also affected at various concentrations of Diazinon, which showed maximum of $2.3 \mu \mathrm{g} \mathrm{chl-a} \mathrm{\textrm {mL } ^ { - 1 }}$ on the $16^{\text {th }}$ day in 5 ppm concentration (Fig. II). The carbohydrate content was found to be higher on the $16^{\text {th }}$ day at $5 \mathrm{ppm}$ concentration $\left(20.3 \mu \mathrm{g} \mathrm{mL}^{-1}\right)$ in $A$. cylindrica and on the $20^{\text {th }}$ day in control $\left(70 \mu \mathrm{g} \mathrm{mL}^{-1}\right)$ culture of O.tenue (Fig. III \&IV). The cellular protein content of both $A$. cylindrical and $O$. tenue in different concentration of Diazinon showed higher content on the $20^{\text {th }}$ and $24^{\text {th }}$ days respectively. It was $52 \mu \mathrm{g}$ of protein $\mathrm{mL}^{-1}$ at $5 \mathrm{ppm}$ in $A$. cylindrica (Fig. V) and $124 \mu \mathrm{g}$ protein $\mathrm{mL}^{-1}$ in $5 \mathrm{ppm}$ culture of O.tenue (Fig. VI). The amino acid content was higher in control cultures of $A$. 
cylindrica and $O$. tenue, especially on the $16^{\text {th }}$ $(33 \mu \mathrm{g} \mathrm{mL})$ and $16^{\text {th }}$ day $\left(36 \mu \mathrm{g} \mathrm{mL} \mathrm{m}^{-1}\right)$ respectively (Fig.VII \& VIII). However, the culture of $O$. tenue resisted up to $5 p \mathrm{pm}$ of Diazinon, which showed the results similar to that of control culture. The nitrogen content in the different concentration of Diazinon by the culture filtrates of $A$. cylindrica was found to be higher on the $20^{\text {th }}$ day in control i.e., $35 \mu \mathrm{g}$ $\mathrm{mL}^{-1}$ (Fig. IX), whereas in case of $O$. tenue was found higher nitrogen content i.e., $34 \mu \mathrm{g}$ $\mathrm{mL}-1$ in $5 \mathrm{ppm}$ concentration at16th day of observation (Fig. $X$ ). Hence, from the above study, it could be concluded that Diazinon treatment have affected the growth in both the isolate even at lower concentration of 3ppm. Based on the inhibitory effect, amino acid was also affected at the earlier stage. Especially in A. cylindrica compared to $O$. tenue, which is in agreement with a study[16], according to whom the instances of tolerance may be attributed to the capacity of the organism to accumulation of chemical in their cells at concentration several fold higher than the surrounding concentration.

\section{Reference}

[1] Das M.K. and Adhikary S.P. (1996) Tropical Agriculture 73;155-157.

[2] Rath B. and Adhikary S.P. (1995) Tropical Agriculture 72; 80-83.

[3] Legahes F. and Ferhandez-Valiente E. (1992) Arch Environ contain Toxical 22; $130-134$.

[4] Padhy (1985) Res Rev as; 144.

[5] Roger P.A. (1996) In; Pingali PL, Roger $P A(e d s)$ Impact of pesticides on Farmer Health and rice environment, 271q1-308. International Rice Research Institute and Kluwer Academic Publishers, Dordrecht. The Netherlands, and Norwell, Mass, USA.

[6] Singh P.K. (1973) Arch. M ikrobiol, 89: $317-320$

[7] Adhikary S. P., Das P. and Pattnaik H. (1984) J. G en. Appl. Microbiol, 35: 335-338.

[8] $\mathrm{T}$ homas S. P and Shanmugasundaram S. (1986) $M$ icrobios. Lett, 33:115-120.

[9] Rath B. and Adhikary S.P. (1995) $T$ rop. Agric, 72: 80-83.

[10] Modi D. R., Singh A. K., Rao K. S., Chakravarty D. and Singh H. N. (1991) Biotechnol Lett. 13; 393-398.

[11] K aushik B.D. and Venkataraman G.S. (1983) Curr. Sci, 52: 321-323.

[12] Tandon R. S., Lal R. and Rao V.V.S. N. (1988) Environ. Pollut, 52: 1-9.

[13] Anand N. and Subramanian T. D. (1997) Phykos, 36: 15-20.

[14] Kapoor K. and Arora I. (2000) Ind. J. Env. Ecoplanning, 3: 219-226.

[15] Selvi G.20 01) Studies on ammonia releasing strains of Cyanobacteria". $P$ h.D ., Thesis, University of
Madras, Chennai, India.

[16] Standyk L., Campbell R.S. and Johnson T. (1971) Bull. Environ. Conta. Toxicol, 6: 1-8. 

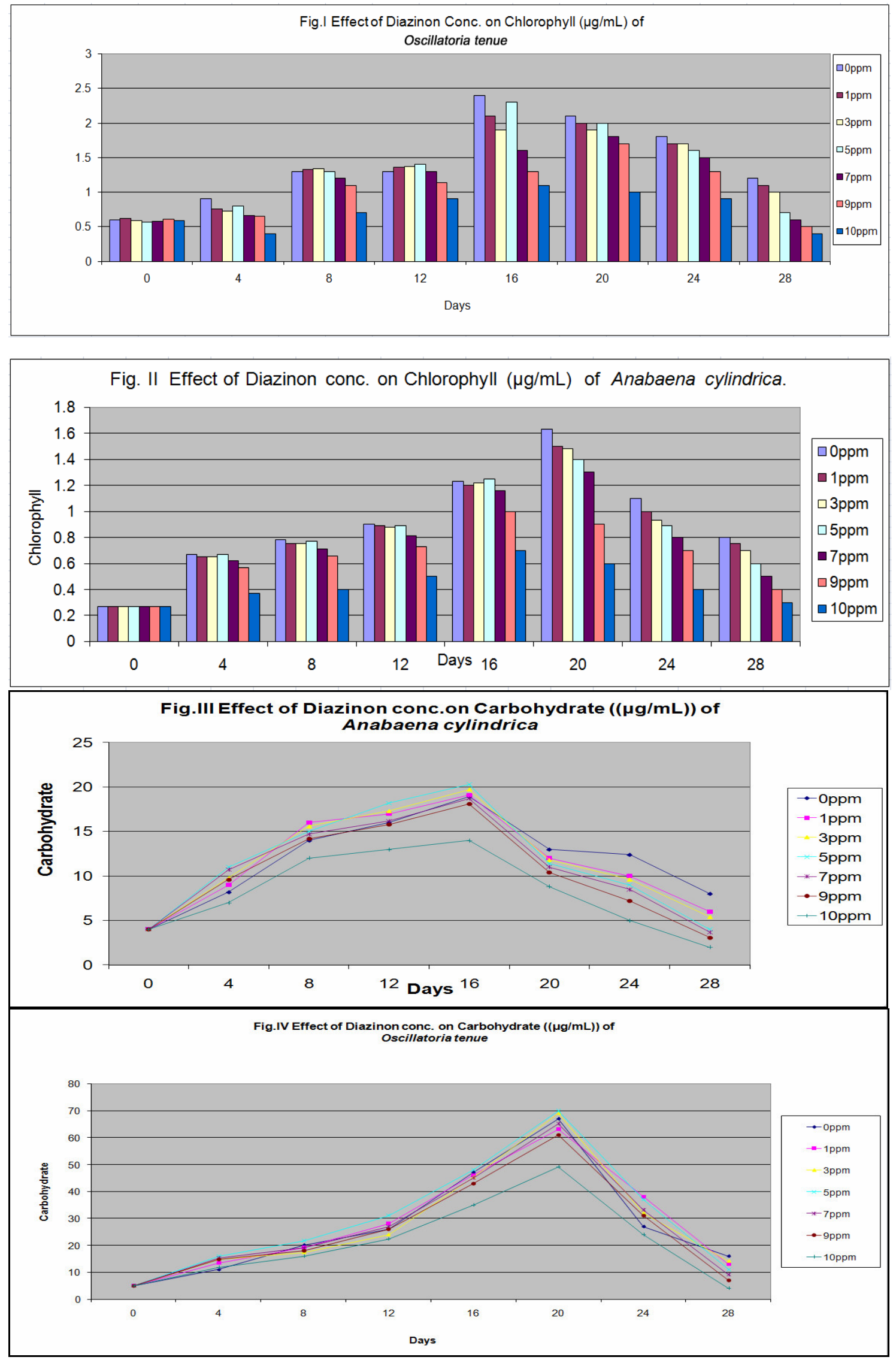


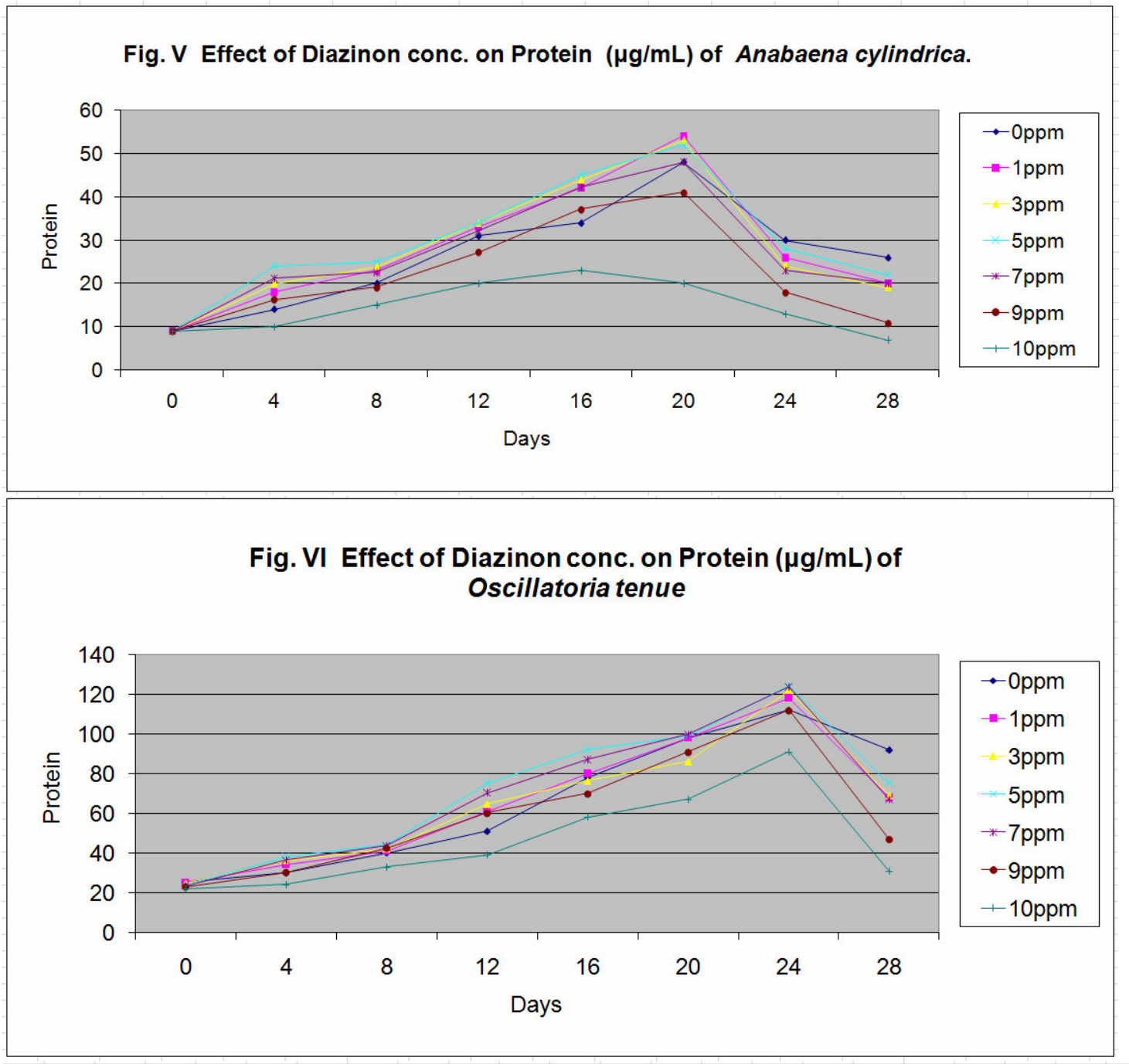

Fig. VII Effect of Diazinon conc. on Amino acid $(\mu \mathrm{g} / \mathrm{mL})$ of Anabaena cylindrica.

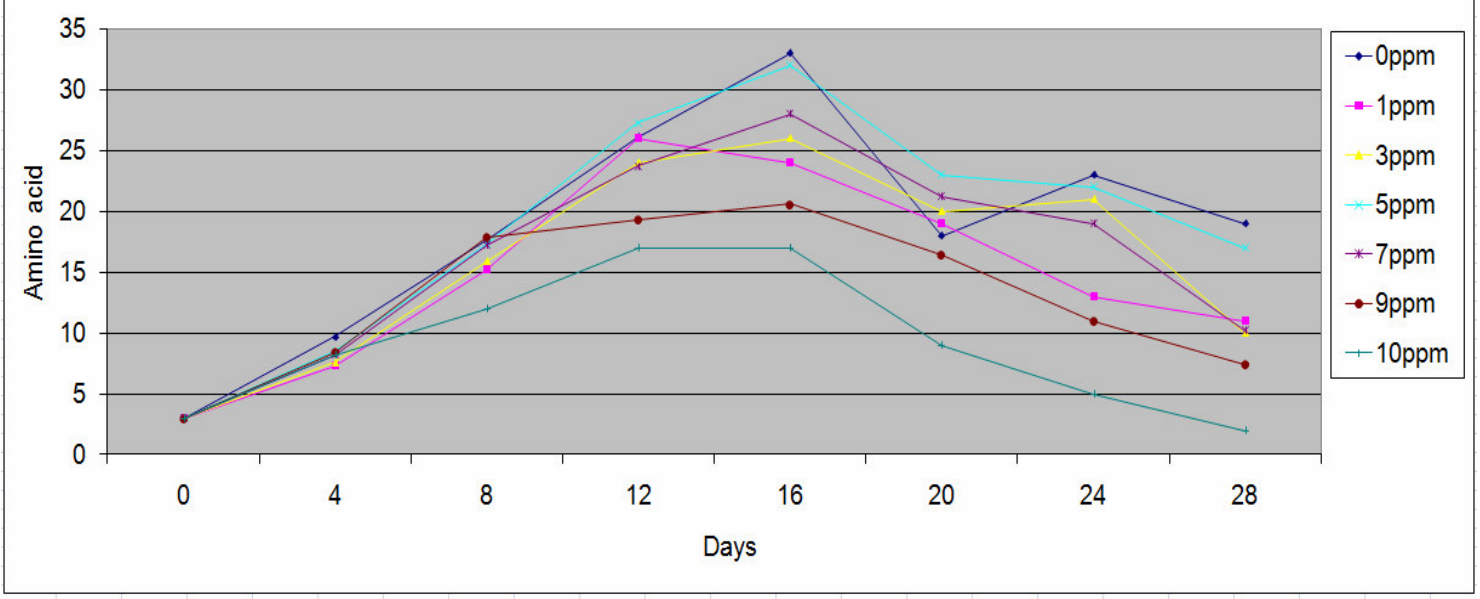



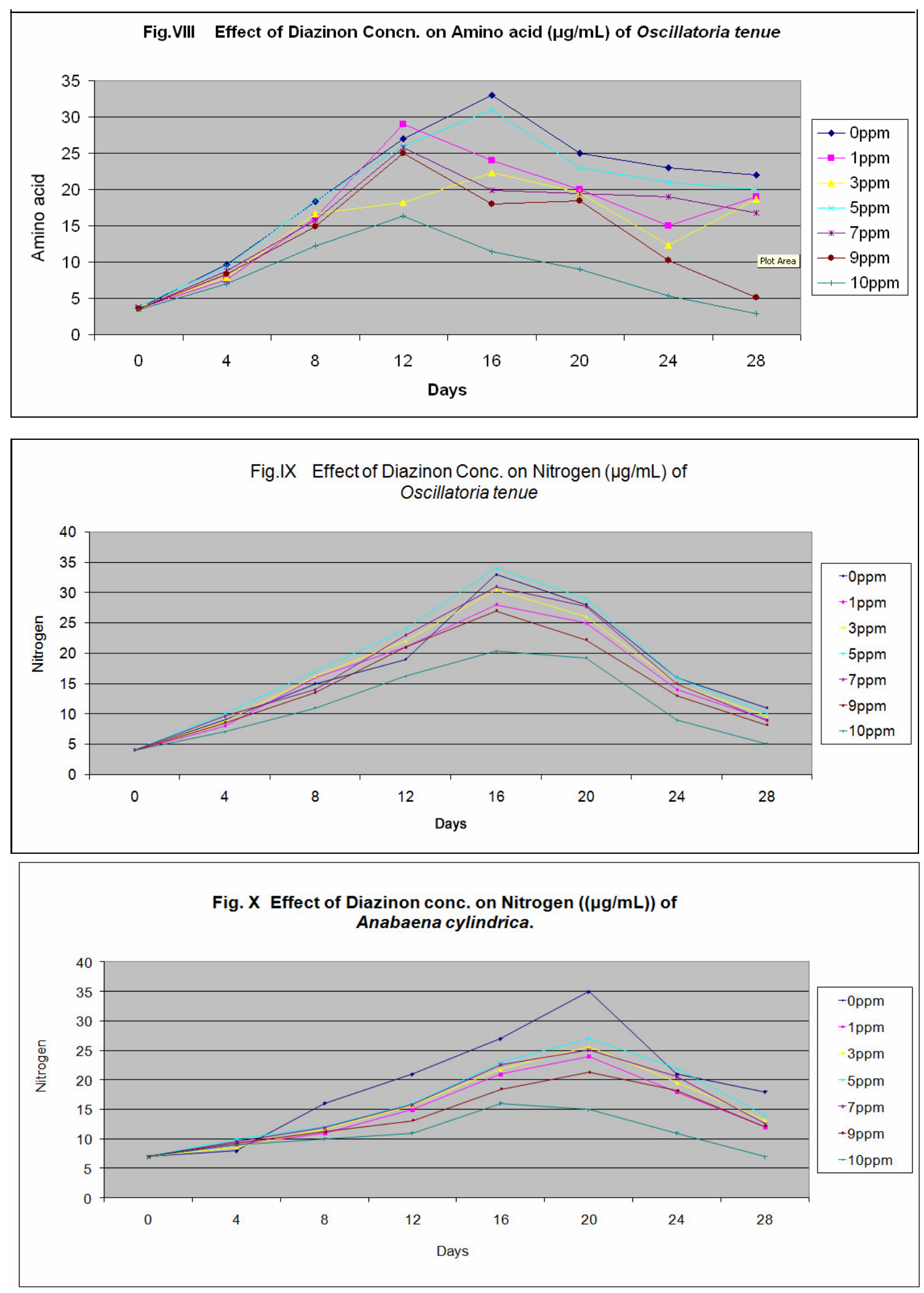